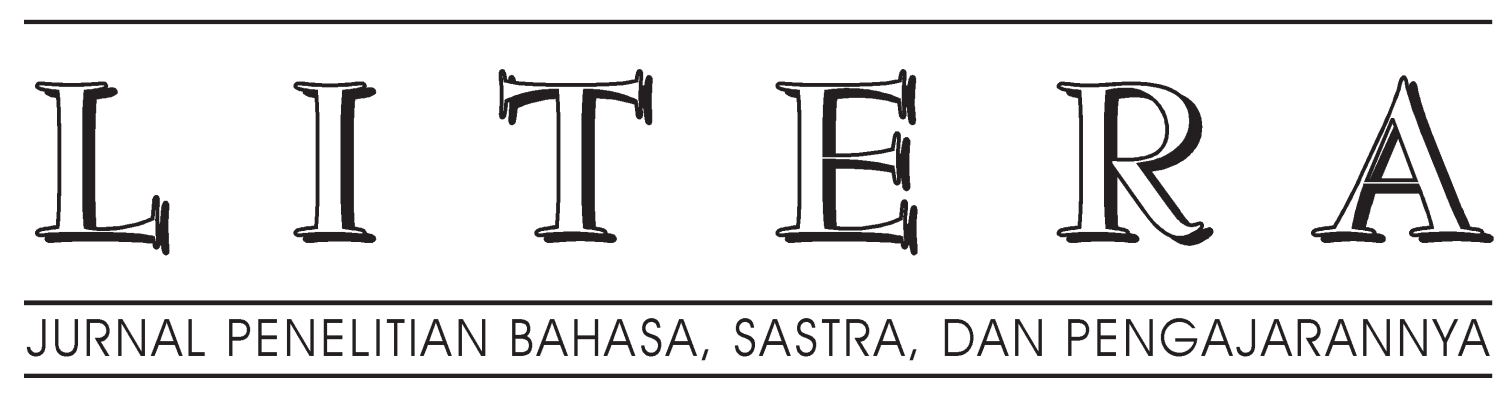

Berdasarkan SK Dirjen Dikti Nomor: 66b/DIKTI/Kep/2011, tanggal 9 September 2011 tentang Hasil Akreditasi Terbitan Berkala Ilmiah, LITERA dinyatakan sebagai Terbitan Berkala Ilmiah Terakreditasi, periode Agustus 2011 sampai dengan Agustus 2016 


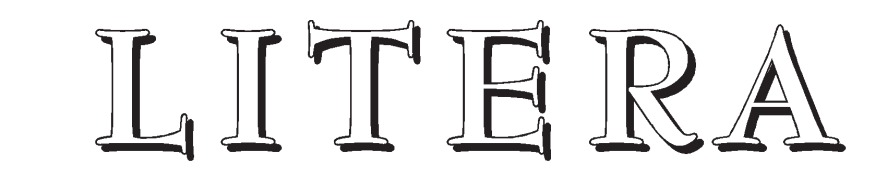

Jurnal Penelitian Bahasa, Sastra, dan Pengajarannya

Volume 12, Nomor 1, April 2013

* Tindak Tutur Direktif Guru dalam Wacana Interaksi Kelas Anak Tunarungu Ardianto 


\title{
TINDAK TUTUR DIREKTIF GURU \\ DALAM WACANA INTERAKSI KELAS ANAK TUNARUNGU
}

\author{
Ardianto \\ SekolahTinggi Agama Islam Negeri Manado \\ email: ardianthotola@yahoo.co.id
}

\begin{abstract}
Abstrak
Penelitian ini bertujuan mendeskripsikan bentuk, fungsi, dan strategi tindak tutur direktif guru dalam wacana interaksi kelas anak tunarungu. Penelitian menggunakan pendekatan kualitatif. Data bersifat alamiah bersumber dari komunikasi yang terjadi dalam interaksi kelas. Hasil penelitian sebagai berikut. Pertama, bentuk tindak tutur direktif meliputi bentuk deklaratif, interogatif, dan imperatif. Kedua, fungsi tindak tutur direktif meliputi fungsi memerintah, meminta, melarang, mengizinkan, menyarankan, mengharapkan, mengajak, menegur, dan memancing. Ketiga, strategi tindak tutur direktif meliputi strategi langsung dan strategi tidak langsung. Realisasi bentuk, fungsi, dan strategi tindak tutur direktif oleh guru berdasarkan keragaman konteks yang melatari wacana percakapan di kelas.
\end{abstract}

Kata kunci: interaksi kelas, tindak tutur direktif, anak tunarungu

\section{THE TEACHER'S DIRECTIVE SPEECH ACTS IN THE DISCOURSE OF DEAF CHILDREN'S CLASSROOM INTERACTION}

\begin{abstract}
This study aims to describe forms, functions, and strategies of the teacher's directive speech acts in the discourse of deaf children's classroom interaction. It employed the qualitative approach. The data were naturalistic in nature, collected from communication occurring in classroom interaction. The findings are as follows. First, the forms include declarative, interrogative, and imperative ones. Second, the functions comprise commands, requests, prohibitions, permissions, suggestions, expectations, invitations, warnings, and elicitations. Third, the strategies consist of direct and indirect ones. The realization of the forms, functions, and strategies of the teacher's directive speech acts is based on a variety of contexts underlying classroom conversation discourse.
\end{abstract}

Keywords: classroom interaction, directive speech acts, deaf children

\section{PENDAHULUAN}

Untuk meningkatkan kemampuan berkomunikasi siswa penyandang tunarungu melalui aktivitas komunikasi yang nyata, pembelajaran bahasa yang diterapkan pada sekolah-sekolah luar biasa adalah pembelajaran bahasa melalui kegiatan percakapan (Direktorat PLB, 2004). Dalam aktivitas percakapan itu, guru memanfaatkan tindak-tindak tutur tertentu sebagai inisiasi untuk menstimulasi respon komunikasi atau bahasa siswa. Guru mempengaruhi siswa selama proses pembelajaran berlangsung dengan memberi pengarahan dan stimulus melalui tindak tutur untuk berpartisipasi dalam konteks percakapan. Jika dipandang dari sudut pandang behavioristik, proses percakapan terkait dengan proses stimulusrespon. Stimulus tertentu dari guru akan 
menimbulkan respon tertentu pula dari siswa, atau sebaliknya. Proses stimulus yang berulang akan menimbulkan kebiasaan atau keteraturan. Dalam konteks wacana interaksi kelas, stimulus-respon ini dapat dilihat pada tuturan yang berfungsi sebagai inisiasi (I) dan diikuti oleh tuturan yang berfungsi sebagai respon $(R)$ yang wujudnya sangat bergantung kepada jenis tuturan awal yang berfungsi sebagai inisiasi.

Pada konteks percakapan itulah, satuan atau unit-unit ekspresi tindak tutur guru tampak dalam komunikasi verbal (dan nonverbal) guru di kelas dalam proses pembelajaran. Salah satu jenis tindak tutur yang lazim digunakan adalah tindak direktif, yaitu tindak tutur yang dilakukan penutur dengan tujuan menghasilkan efek berupa tindakan yang dilakukan oleh penutur. Berbagai penelitian berbasis interaksi kelas yang dilakukan menunjukkan bahwa jenis tindak tutur tersebut merupakan salah satu dari beragam jenis tindak tutur yang banyak digunakan guru dalam interaksi lisan dengan siswa di kelas. Hal ini ditunjukkan dalam beberapa penelitian tindak tutur berbasis interaksi kelas seperti yang dilakukan oleh Bellack, dkk. (1966), Sinclair dan Coulthard (1975), Coulthard (1978), dan Burton (1981), Barnes (1992), Cazden (1972). Dalam beberapa penelitian itu, dikemukakan antara lain tindak direktif digunakan guru pada tahap pembukaan pembelajaran, tahap inti pembelajaran, dan tahap akhir atau penutup pembelajaran dengan berbagai fungsi. Fungsi-fungsi yang dimaksud ialah untuk mempersiapkan suasana kelas agar siswa memiliki kondisi siap dalam memulai pembelajaran, untuk memperaktif siswa dalam proses pembelajaran, dan untuk mengetahui daya serap siswa terhadap materi yang telah dipelajari (lihat Sinclair dan Coulthard, 1975; dan Chaudron, 1988).

Temuan penggunaan tindak tutur direktif oleh guru dalam interaksi kelas juga ditunjukkan penelitian Jumadi (2005) dan Karim (2005). Hasil penelitian Jumadi (2005), misalnya, yang berfokus pada penggunaan power dalam kelas menunjukkan bahwa power yang direpresentasikan dalam tindak tutur guru pada umumnya diwujudkan dalam tindak-tindak direktif selain tindak asertif dan tindak ekspresif. Demikian pula, hasil penelitian Karim (2008) yang berfokus pada penggunaan imperatif dalam interaksi pembelajaran di kelas menunjukkan bahwa dalam interaksi antara guru dan siswa pada proses pembelajaran di kelas, tindak tutur guru pada umumnya bersifat direktif yang diwujudkan dalam beragam fungsi seperti fungsi memerintah, meminta, melarang, mengizinkan, memberi saran, mengharapkan, dan mengajak.

Tingginya frekuensi penggunaan tindak direktif oleh guru dalam interaksi lisan di kelas tidak terlepas dari karakteristik wacana kelas. Dalam kaitan dengan ini, Fairclough (1998:83) memandang bahwa sekolah mempunyai tatanan sosial dan tatanan wacana yang melibatkan struktur ruang sosial tersendiri. Hal itu tampak dalam berbagai hal, yakni pada seperangkat situasi terjadinya wacana itu, seperangkat peranan sosial yang diakui oleh orangorang yang berpartisipasi dalam wacana itu, dan seperangkat tujuan yang diakui untuk wacana itu-pembelajaran, ujian, pemeliharaan kontrol sosial.

Dalam interaksi kelas, guru memiliki kekuasaan dan kontrol terhadap siswa. Siswa sebagai mitra tutur guru di kelas mempunyai status yang lebih rendah sehingga mereka dapat diatur dalam batasbatas tertentu. Pemilikan kekuasaan dan kontrol terhadap siswa itu merupakan peran khusus dari guru di kelas seperti yang dikemukakan oleh Stubbs (1983). Berdasarkan peran yang dimilikinya itu, guru mengelola kelas, mengatur siapa, berapa, dan kapan siswa berbicara, mengatur jenis pertanyaan dengan memanfaatkan tindak tutur, khususnya tindak 
ilokusi, mengevaluasi jawaban siswa, dan memberikan umpan balik. Dalam konteks inilah, tindak tutur termasuk tindak tutur direktif digunakan oleh guru untuk menyampaikan fungsi-fungsi komunikasi tertentu dalam interaksi pembelajaran di kelas.

Penggunaan tindak tutur direktif guru haruslah seefektif mungkin agar tujuantujuan interaksi pembelajaran di kelas dapat tercapai secara maksimal. Keefektifan tindak tutur guru termasuk tindak tutur direktif dalam kelas penting karena kelas secara potensial merupakan tempat di mana siswa dapat belajar dan mempraktekkan keterampilan untuk meningkatkan kemampuan komunikatifnya (Sinclair dan Brazil, 1982:6). Selain itu, kebermaknaan pembelajaran melalui interaksi lisan guru dan siswa di kelas antara lain dipengaruhi oleh penggunaan bahasa oleh guru. Bahasa yang digunakan oleh guru di dalam kelas dapat mempengaruhi kesuksesan interaksi pembelajaran (Cook, 2000:114; Parrish, 2004:175).

Untuk memelihara kebermaknaan pembelajaran melalui interaksi lisan di kelas itu, bahasa guru atau tindak tutur guru sangatlah strategis. Terutama pada kondisi kelas berkebutuhan khusus, yaitu kondisi siswa tunarungu, tindak tutur guru sangat membantu siswa dalam pembelajaran. Kemampuan guru dalam melakukan tindak bahasa (tindak tutur) sesuai dengan konteks, topik, hubungan sosial, dan hubungan psikologisnya akan menentukan tingkat keefektifan komunikasi guru dengan siswa selama kegiatan pembelajaran di kelas. Bagaimanakah wujud tindak tutur guru khususnya tindak tutur direktif dalam wacana interaksi kelas anak tunarungu? Masalah inilah yang menjadi kajian utama dalam penelitian ini. Masalah tersebut diarahkan pada tiga fokus kajian, yaitu (1) penggunaan bentuk, (2) fungsi, dan (3) strategi tindak tutur direktif guru dalam wacana interaksi kelas anak tunarungu dengan menggunakan rancangan teori pragmatik.

\section{METODE}

Penelitian ini menggunakan pendekatan kualitatif. Data dikumpulkan dari latar alamiah, yaitu komunikasi yang terjadi dalam interaksi kelas di SLB-B, peneliti bertindak sebagai instrumen kunci (key instrument), dan lebih mengutamakan proses di samping hasil. Penelitian dilaksanakan pada SMALB Yayasan Pendidikan Tunas Bangsa (YPTB) Malang.

Data penelitian terdiri atas dua jenis, yaitu: (a) data tuturan dan (b) data catatan lapangan. Data tuturan mengandung bentuk, fungsi, dan strategi tindak tutur direktif guru. Data catatan lapangan meliputi catatan lapangan deskriptif dan catatan lapangan reflektif. Data dikumpulkan melalui observasi nonpartisipan secara langsung sambil melakukan perekeman dan pencatatan (catatan lapangan). Alat bantu perekaman dalam kegiatan observasi berupa perekam Digital Vidio Camera Recorder (Handycam). Analisis data dilakukan melalui beberapa tahapan, yaitu (a) pengklasifikasian data dan (b) data yang telah dikelompokkan dianalisis menggunakan model interaktif (Miles dan Huberman, 1992) dengan empat tahap, yaitu: (1) pengumpulan data, (2) pereduksian data, (3) penyajian data, dan (4) penyimpulan temuan dan verifikasi. Pengecekan keabsahan data dilakukan dengan (1) perpanjangan keikutsertaan, (2) ketekunan pengamatan, (3) triangulasi, baik triangulasi sumber data (hasil perekaman dan catatan lapangan), maupun triangulasi metode (wawancara dan pengamatan), dan (4) pemeriksaan teman sejawat.

\section{HASIL DAN PEMBAHASAN \\ Bentuk Tindak Tutur Direktif Guru}

Dari penelitian yang dilakukan dapat dipaparkan bahwa tindak tutur direktif guru dalam wacana interaksi kelas diwujudkan dalam modus tuturan deklaratif, interogatif, dan imperatif. Sebagai bentuk direktif, tuturan dengan modus deklaratif, 
interogatif, dan imperatif dapat menggunakan pilihan bahasa dan variasi linguistik tertentu.

\section{Tindak Tutur Direktif Guru dengan Mo- dus Deklaratif}

Dalam wacana interaksi kelas anak tunarungu, temuan penelitian menunjukkan bahwa tindak tutur direktif guru yang diwujudkan dalam modus deklaratif terdiri atas tujuh kategori, yaitu bermodus pernyataan keinginan, bermodus pernyataan keharusan, bermodus pernyataan larangan, bermodus pernyataan pengizinan, bermodus pernyataan ajakan, bermodus pernyataan kritik, dan bermodus pernyataan teguran. Berikut adalah contoh tuturan yang mengandung tindak tutur direktif dalam modus deklaratif berupa pernyataan keinginan yang merepresentasikan fungsi permintaan yang ditandai dengan penggunaan modalitas mau secara eksplisit.

[1] Guru : (a) Hari ini kita mau belajar bermain drama Tangkuban Perahu. (b) Masih ingat kemarin bagaimana senang, bagaimana sedih, bagaimana marah?

Siswa : (c) Masih.

Konteks: Dituturkan guru dalam interaksi pembelajaran di kelas ketika guru membuka pelajaran.

Kutipan [1] tersebut merupakan bentuk tindak tutur direktif dalam modus deklaratif berupa pernyataan keinginan. Dalam tuturan itu, guru menyatakan keinginan dengan menggunakan penanda kata mau dalam tuturan. Dalam tuturan tersebut, guru menginformasikan bahwa pelajaran bahasa Indonesia hari ini adalah bermain drama Tangkuban Perahu. Karena tindak ini hanya berupa informasi, maka tidak ada reaksi verbal yang diharapkan. Guru juga tampaknya tidak mengharapkan demikian. Karena guru ingin mengetahui apakah siswa masih mengingat atau menguasai materi yang telah diberikan, maka guru mengajukan pertanyaan pada tuturan (b). Respon siswa berbentuk jawaban yang bersifat verbal, seperti yang terlihat pada tuturan (c).

\section{Tindak Tutur Direktif Guru dengan Mo- dus Interogatif}

Dalam wacana interaksi kelas anak tunarungu, temuan penelitian menunjukkan bahwa tindak tutur direktif guru juga diwujudkan dalam modus interogatif. Dengan kata lain, tuturan yang diwujudkan dalam modus interogatif mengandung ilokusi direktif untuk meminta atau memerintah siswa melakukan sesuatu sebagaimana diharapkan guru. Data temuan penelitian menunjukkan bahwa direktif bermodus interogatif atau kalimat pertanyaan terdiri atas lima kategori, yaitu pertanyaan permintaan klarifikasi, permintaan informasi, permintaan konfirmasi, pertanyaan bermodus alasan, dan permintaan tindakan. Contoh tuturan direktif yang diwujudkan dalam bentuk interogatif yang merepresentasikan tindak direktif sebagai berikut.

[2] Guru : (a) Nia buat apa? (b) Oh, buat bunga kok putih? (c) Ini untuk tutupnya tisu. (d) Nah ini manis ((SAMBIL MENUNJUK CONTOH RANGKAIAN BUNGA YANG SUDAH DIKERJAKAN OLEH SISWA LAIN)). (e) Terlalu besar lho. (f) Kan terlalu besar, jadi kurang manis.

Nia : ((MEMPERHATIKAN SECARA SEKSAMA PEMBICARAAN GURU))

Konteks: Dituturkan guru dalam interaksi pembelajaran di kelas (ruang praktek) ketika siswa sedang praktek keterampilan tata busana. Seorang siswa menggunakan pita warna putih dalam merangkai bunga asesoris penutup tisu. 
Data tuturan (b) pada kutipan [2] merupakan tindak direktif dengan modus interogatif berupa pertanyaan permintaan klarifikasi. Guru bertanya untuk meminta klarifikasi kepada siswa tentang warna yang dipilih dalam membuat rangkaian bunga yang terbuat dari pita untuk asesoris penutup tempat tisu. Tuturan (b) dalam modus bertanya merupakan tuturan yang berfungsi direktif dalam arti guru meminta siswa untuk menjelaskan tindakannya membuat rangkaian bunga. Melalui tuturan tersebut, guru tidak sekadar melakukan tindak bertanya untuk meminta klarifikasi, tetapi juga melakukan tindak menegur dengan modus interogatif. Fungsi direktif tuturan (b) tersebut ialah meminta agar siswa memilih warna yang sesuai agar rangkaian bunga yang digunakan sebagai asesoris penutup tisu tampak menarik.

\section{Tindak Tutur Direktif Guru dengan Mo- dus Imperatif}

Dalam wacana interaksi kelas, penggunaan tuturan dengan modus imperatif sangat potensial digunakan guru. Di dalam kelas, guru memiliki kedudukan yang lebih tinggi daripada siswa. Bahkan dalam batas-batas tertentu, guru mengatur, mengarahkan, memerintah, meminta siswa untuk berpartisipasi dalam proses pembelajaran. Kedudukan seperti itu memungkinkan guru menggunakan tuturan dengan modus imperatif langsung untuk menyatakan perintah, permintaan, atau larangan dalam interaksi pembelajaran di kelas.

Data temuan penelitian menunjukkan bahwa dalam wacana interaksi kelas anak tunarungu, tindak tutur direktif guru yang diwujudkan dalam modus imperatif terdiri atas delapan kategori, yaitu bermodus imperatif perintah, imperatif suruhan, imperatif permintaan, imperatif larangan, imperatif ajakan, imperatif saran, imperatif harapan, dan imperatif desakan. Contoh penggunaan direktif bentuk imperatif perintah yang lazim digunakan guru sebagaimana dicontohkan dalam tuturan berikut.

[3] Guru : (a) Kasihan, nanti tidak bisa bagaimana? (b) Sekarang diberi kesempatan untuk membuat puisi, perkenalan besok lagi! (c) Sekarang bicara ya, diganti puisi.

Siswa : (BINGUNG KARENASISWA TIDAK MEMBAWA PUISI YANG TELAH DITULIS DI RUMAH))

Guru : (d) Belum membawa?

Panca: (e) Apa?

Guru : (f) Puisi, sekarang membuat!

Sita : (g) Apa bu? puisi?

Guru : (h) $\mathrm{Pu}-\mathrm{i}-\mathrm{si}$, judul bebas.

Siswa: ((MENGELUARKANKERTAS

UNTUK MEMBUAT PUISI))

Konteks: Dituturkan guru dalam interaksi pembelajaran di kelas. Guru memberikan kesempatan kepada siswa untuk menulis kembali puisi karena puisi yang telah ditugaskan di rumah tidak dibawa atau belum dikerjakan siswa. Tuturan guru itu disertai dengan gerak tubuh dan isyarat jari.

Tindak tutur direktif guru pada data tuturan (b) dan (f) kutipan [3] direalisasikan dalam modus imperatif perintah. Tindak perintah guru tersebut diperjelas dengan menggunakan isyarat gerak tubuh dan isyarat jari. Tuturan (b) dan (f) itu muncul karena siswa tidak membawa tugas puisi yang telah ditugaskan pada pertemuan sebelumnya. Guru telah menugaskan siswa membuat puisi di rumah dan akan dibacakan di kelas, namun siswa ternyata tidak membawa puisi atau belum mengerjakan tugasnya. Oleh karena itu, guru memerintahkan kembali siswa untuk membuat puisi. Tindak perintah guru pada tuturan (a) tidak direspon siswa, bahkan sebaliknya siswa kebingungan. Menyadari kebingungan siswa, guru kemudian bertanya 
sebagaimana tampak pada tuturan (d). Pertanyaan guru ini direspon oleh siswa dengan tuturan interogatif pada tuturan (e) yang kemudian direspon kembali oleh guru dengan tuturan imperatif berupa tindak perintah pada tuturan (f). Tindak perintah guru pada tuturan (f) direspon oleh siswa dengan tindak bertanya pada tuturan (g). Secara deklaratif, guru pada tuturan (h) menjawab pertanyaan siswa yang sekaligus sebagai tindak penegasan guru tentang perintahnya untuk membuat puisi.

\section{Fungsi Tindak Tutur Direktif Guru}

Data temuan penelitian menunjukan bahwa fungsi tindak tutur direktif guru dalam wacana interaksi kelas anak tunarungu yang direpsentasikan oleh tuturan dengan beragam modus diklasifikasikan ke dalam sembilan kategori, yaitu fungsi memerintah, meminta, melarang, mengizinkan, menyarankan, mengharapkan, mangajak, menegur, dan memancing. Kesembilan fungsi tindak tutur direktif tersebut lazim digunakan guru dalam interaksi lisan dengan siswa di kelas, baik penyampaiannya dengan tuturan langsung (eksplisit), maupun tidak langsung (implisit). Fungsi-fungsi direktif yang direpresentasikan dalam berbagai modus tuturan tersebut berkaitan dengan kegiatan guru mengarahkan siswa, menunjuk untuk melakukan sesuatu terkait dengan tugas pembelajaran, mengaktifkan siswa berbicara, dan mendorong keterlibatan atau partisipasi siswa dalam proses pembelajaran. Kutipan berikut merupakan jenis fungsi direktif memerintah dalam bentuk penunjukan siswa untuk melakukan sesuatu terkait dengan tugas pembelajaran.

[4] Guru : (a) Ade sudah?

Ade : (b) Sudah (b)

Guru : (c) Sambil menunggu teman lain, coba Ade belajar memperkenalkan diri seperti contoh ini! (c)
Ade : (d) Ya (d) ((SAMBIL BERDIRI DANBERJALANKEDEPAN))

Guru : (e) Untuk nama diganti nama sendiri!

Ade : (f) Nama sendiri

Konteks: Dituturkan guru dalam interaksi pembelajaran di kelas. Guru menyuruh salah seorang siswa (Ade) untuk memperkenalkan diri sesuai contoh yang ada.

Fungsi tindak tutur direktif sebagaimana tampak pada tuturan (c) kutipan [4] adalah memerintah, yaitu guru melalui tuturan itu memerintahkan siswa untuk memperkenalkan diri dengan mengikuti contoh yang ada. Tuturan dengan modus imperatif itu merupakan tindak memerintah guru yang dilakukan secara halus. Penggunaan kata coba menurunkan kadar retriksi tuturan yang mempunyai ilokusi perintah itu. Dalam konteks interaksi kelas anak tunarungu tindak memerintah seperti ini seringkali dilakukan oleh guru. Cara seperti ini, merupakan salah satu strategi guru untuk mengakrabkan dirinya dengan siswa sehingga siswa dapat melaksanakan perintah guru secara riang atau tidak dibawa tekanan. Nilai keakraban guru dengan siswa itu semakin terasa dengan menggunakan sapaan berupa nama sebagaimana terdapat dalam data tuturan (c).

\section{Strategi Tindak Tutur Direktif Guru}

Dalam wacana interaksi kelas anak tunarungu, data temuan penelitian menunjukkan bahwa perealisasian tindak tutur direktif guru dilakukan dengan menggunakan strategi bertutur langsung dan strategi bertutur tidak langsung. Pilihan strategi bertutur guru tersebut terkait dengan tujuan komunikasi yang ingin dicapai dalam konteks pembelajaran. Temuan penelitian menunjukkan bahwa guru menggunakan strategi langsung dan tidak langsung dalam mengungkapkan beragam maksud tindak direktifnya pada 
interaksi pembelajaran di kelas. Berkaitan dengan penggunaan strategi langsung, hal ini digunakan guru untuk mengekspresikan fungsi memerintah, meminta, melarang, mengizinkan, menyarankan, mengharapkan, dan menegur. Dalam hal lain, strategi tidak langsung juga digunakan untuk menyatakan fungsi direktif memerintah, meminta, melarang, menegur, dan memancing.

Data temuan penelitian menunjukkan bahwa penggunaan bentuk direktif yang merepresentasikan fungsi direktif tertentu direalisasikan secara beragam sesuai dengan konteks yang melatari wacana percakapan di kelas dan kebutuhan komunikasi serta tujuan yang hendak dicapai dalam interaksi lisan di kelas. Contoh penggunaan tindak direktif guru dengan strategi langsung pada wacana interaksi kelas anak tunarungu menggunakan pernyataan keharusan ketika memerintahkan siswa untuk terus berlatih berbicara.

[5] Guru : (a) Riska!

Riska : ((MEMPERKENALKAN DIRI))

Guru : (b) Ya, Susi!

Susi : ((MEMPERKENALKAN DIRI))

Guru : (c) Bagus! (d) Semua harus latihan lagi bicara yang jelas!

Siswa : ((MEMPERHATIKAN))

Konteks: Dituturkan guru dalam interaksi pembelajaran di kelas ketika dua orang siswa, Riska dan Susi, telah tampil memperkenalkan diri. Guru meminta kembali semua siswa untuk latihan berbicara.

Tuturan (d) pada kutipan [5] merupakan bentuk direktif perintah dengan modus imperatif langsung. Dalam tuturan perintah itu ditandai dengan penggunaan kata harus yang menunjukkan bahwa perintah guru itu merupakan sebuah keharusan. Penekanan perintah keharusan ini didasarkan pada evaluasi guru terhadap kemampuan siswa mengartikulasikan kata yang belum semuanya jelas. Hal ini merupakan penekanan dari program layanan pendidikan bagi anak tunarungu yaitu pada tercapainya kemampuan berkomunikasi siswa secara verbal. Untuk tujuan itulah, guru memerintahkan siswa agar terus berlatih berbicara. Tindak memerintah guru yang direpresentasikan dalam tuturan (d) itu bersifat keras dan terkesan menekan atau memaksa.

Tindak direktif ada juga yang diekspresikan dengan menggunakan tuturan tidak langsung atau makna yang dimaksudkan tidak sama dengan apa yang tampak dalam modus tuturan. Kutipan berikut merupakan contoh penggunaan strategi perintah tidak langsung dengan modus interogatif.

[6] Guru : (a) Siapa yang bertanya?

Siswa : ((DIAM))

Guru : (b) (//Bertanya//)! (c) Bu Ludfi saya (//tidak tahu//). ((GURU MENUNJUK SITA))

Sita :((TIDAK BERTANYA))

Konteks: Dituturkan guru kepada siswa dalam interaksi pembelajaran di kelas ketika guru selesai menjelaskan materi dan memberikan kesempatan siswa untuk bertanya tentang materi yang telah dijelaskan

Tuturan (a) pada kutipan [6] merupakan bentuk direktif perintah dengan modus interogatif. Tindak perintah guru ini direalisasikan dengan menggunakan tuturan perintah tidak langsung dengan modus interogatif. Dengan modus tuturan tersebut, guru tidak hanya sekadar melakukan tindak bertanya, tetapi juga merupakan tindak perintah. Penegasan bahwa tuturan (a) merupakan suatu perintah ditegaskan guru dalam tuturan (b) ketika siswa tidak merespon tuturan guru. Bahkan guru melakukan penunjukkan langsung agar siswa bertanya. Penunjukkan oleh guru itu berisi direktif yaitu perintah agar siswa yang ditunjuk bertanya. Penunjukan oleh guru ini merupakan tindak mendorong siswa 
untuk aktif dalam proses pembelajaran. Penyebutan nama siswa yang dilakukan guru juga tidak menghasilkan respon dari siswa sebagaimana diharapkan guru. Dengan demikian, tindak perintah guru dengan modus tuturan tidak langsung dalam konteks ini dapat dianggap tidak efektif.

Berdasarkan deskripsi temuan penelitian yang telah dipaparkan dapat dikemukakan bahwa tindak tutur direktif guru dalam wacana interaksi kelas anak tunarungu direpresentasikan secara beragam melalui wujud, fungsi, dan strategi bertutur tertentu. Bentuk, fungsi, dan strategi tindak tutur direktif yang direalisasikan guru berdasarkan pada keragaman konteks yang melatari wacana percakapan di kelas. Pembahasan tentang temuan bentuk, fungsi, dan strategi tindak tutur direktif guru dipaparkan berikut ini.

Pertama, dilihat dari segi modus tuturan, bentuk tindak tutur direktif guru diwujudkan dengan tuturan modus deklaratif, interogatif, dan imperatif. Ketiga kategori wujud bentuk tindak tutur direktif tersebut merepresentasikan fungsifungsi direktif sesuai dengan kebutuhan komunikasi dalam konteks interaksi lisan guru dengan siswa di kelas. Dalam wacana interaksi kelas, penggunaan bentuk direktif terkait dengan jenis tindak direktif tertentu. Dalam kaitannya dengan jenis tindak direktif tertentu, penggunaan bentuk ditektif mempunyai pola atau ciri tertentu. Pola atau ciri tersebut dipengaruhi oleh konteks penggunaannya dalam wacana atau percakapan saat pembelajaran di kelas. Menurut Mey (1993:39), konteks lebih dari sekadar masalah acuan dan pemahaman terhadap sesuatu yang sesungguhnya dimaksudkan, konteks menjadikan makna ujaran-ujaran kita lebih mendalam. Hal itu dijelaskan juga oleh Sperber dan Willson (2009) bahwa untuk memperoleh relevansi secara maksimal, kegiatan berbahasa harus melibatkan dampak kontekstual. Semakin besar dampak kontekstual sebuah percakapan, semakin besar pula relevansinya.

Pada umumnya, temuan-temuan penelitian ini menunjukkan bahwa konteks merupakan bagian yang tidak terpisahkan dengan tuturan. Setiap tindak direktif yang dituturkan oleh guru, inferensinya selalu berdasarkan konteks tuturan. Hal itu menunjukkan bahwa peran konteks sangat dominan dalam tindak tutur direktif guru. Konteks menentukan wujud tindak tutur direktif guru yang direalisasikan dalam interaksi pembelajaran di kelas. Hal tersebut sejalan dengan pandangan Wijana (1996) bahwa bentuk tindak tutur dapat berupa tuturan dalam berbagai modus seperti deklaratif, interogatif, dan imperatif langsung atau tidak langsung, makna literal atau tidak literal. Berkaitan dengan penggunaan modalitas dalam suatu tuturan, Fairclough (1998:127) menjelaskan bahwa modalitas merupakan salah satu hal yang penting dari nilai peseta tutur. Berkaitan dengan penggunaan pilihan kata, Tannen (1994:22) menyatakan bahwa penggunaan kata berkaitan dengan kewenangan (power) dan solidaritas. Misalnya, penggunaan kata sapaan dalam wacana interaksi kelas tidak dapat dilepaskan dari pertimbangan tentang peran partisipan tutur, yaitu siapa penutur dan siapa mitra tutur.

Kedua, dilihat dari segi realisasi fungsi direktif, berdasarkan deskripsi temuan penelitian dapat dikemukakan bahwa fungsi tindak tutur direktif guru dalam wacana interaksi kelas anak tunarungu meliputi fungsi memerintah, meminta, melarang, mengizinkan, menyarankan, mengharapkan, mangajak, menegur, dan memancing. Fungsi-fungsi direktif yang diekspresikan tersebut, jenisnya dan penggunaannya beragam, serta mempunyai pola dan ciri tertentu. Pola atau ciri tersebut dipengaruhi oleh konteks penggunaannya dalam wacana interaksi kelas atau pembelajaran di kelas. Penggunaan fungsi tindak direktif memerintah, misalnya, ada yang disam- 
paikan dengan tuturan modus imperatif langsung, namun ada pula yang disampaikan dengan modus interogatif, atau deklaratif. Penyampaian fungsi direktif perintah dalam berbagai modus tersebut terkait dengan tujuan komunikasi yang ingin dicapai. Jika guru mengharapkan agar perintahnya itu segera dilaksanakan, guru cenderung menggunakan modus tuturan imperatif langsung sehingga terkesan tegas dan menekan atau memaksa. Demikian pula, penyampaian fungsi direktif permintaan umumnya juga menggunakan modus tuturan imperatif langsung, namun juga dalam konteks tertentu digunakan modus interogatif atau deklaratif. Fungsi-fungsi direktif yang direpresentasikan dalam berbagai modus tuturan tersebut pada umumnya dimaksudkan atau digunakan guru untuk menstimulasi siswa untuk berkomunikasi, mengarahkan dan mendorong keaktifan siswa, dan menegakkan kedisiplinan siswa. Selanjutnya, fungsi mengizinkan, menyarankan, mengharapkan, dan mengajak mengimplikasikan suatu perintah atau permintaan yang bersifat halus. Hal ini berbeda dengan penyampaian fungsi menegur yang umumnya menggunakan modus tuturan yang terkesan menekan atau memaksa.

Berdasarkan realisasi fungsi direktif, dapat dikemukakan bahwa dalam wacana interaksi kelas anak tunarungu, fungsi tindak direktif guru, jenis dan penggunannya beragam. Dalam hal ini, fungsi tindak direktif diekspresikan dengan tuturan bermodus imperatif, deklaratif, dan interogatif. Dalam pengekspresiannya dengan tuturan dalam berbagai modus, tiap fungsi tindak direktif tersebut ditandai oleh pilihan bentuk linguistik tertentu, seperti modalitas, pilihan kata, dan atau intonasi tertentu. Kenyataan tersebut dapat dikatakan sebagai ciri atau pola penggunaan fungsi tindak direktif dalam konteks wacana interaksi kelas. Secara teoretis, hal itu sejalan dengan pandangan yang dikemukakan Fairclough (1998:127) yang menyatakan bahwa modalitas merupakan salah satu hal yang penting dari nilai relasional dan nilai ekpresif gramatika.

Ketiga, dilihat dari segi penggunaan strategi tindak tutur direktif, temuan penelitian menunjukkan bahwa dalam wacana interaksi kelas anak tunarungu, strategi tindak direktif terkait dengan jenis tindak direktif tertentu. Dalam kaitannya dengan jenis tindak direktif tertentu, penggunaan strategi direktif mempunyai ciri dan pola tertentu. Pola atau ciri tersebut dipengaruhi oleh konteks penggunaannya dalam wacana kelas atau pembelajaran di kelas. Dalam hal ini, strategi penyampaian tindak direktif berupa strategi langsung yang dinyatakan dengan tuturan bermodus imperatif dan strategi yang dinyatakan dengan tuturan modus deklaratif atau interogatif. Akan tetapi, dalam penuturan guru, strategi penyampaian tindak direktif umumnya berupa strategi langsung. Penggunaan strategi langsung tersebut dilakukan guru untuk memerintah, meminta, melarang, mengizinkan, menyarankan, mengharapkan, dan menegur. Kelangsungan tuturan tersebut ditandai oleh penggunaan tuturan yang secara harfiah dan secara pragmatis makna yang diungkapkan jelas. Hal itu senada dengan penjelasan Searle (dalam Martinich, 2001:176) bahwa berbagai kasus makna yang paling sederhana adalah kasus-kasus di mana penutur mengujarkan sebuah kalimat dan memaksudkan secara tepat dan secara harfiah apa yang ia katakan.

Selain penggunan strategi langsung, data temuan penelitian juga menunjukkan adanya penggunaan strategi tidak langsung dalam penyampaian fungsi direktif tertentu seperti untuk memerintah, meminta, melarang, dan menegur. Ninio dan Snow (1996:138) mengemukakan bahwa ada berbagai macam cara tidak langsung yang digunakan penutur dalam 
mengomunikasikan keinginannya agar suatu tindakan tertentu dilakukan oleh penutur. Adanya penggunaan strategi tersebut menunjukkan bahwa dalam wacana interaksi kelas anak tunarungu saat pembelajaran berlangsung, guru berupaya mengutarakan maksud secara efektif dan efisien untuk mencapai tujuan komunikasi terkait dengan tujuan pembelajaran yang hendak dicapai. Hal itu sejalan dengan yang dikemukakan Searle (dalam Martinich, 2001) dan Kartomihardjo (1993) bahwa penggunaan strategi langsung dilakukan agar segera atau mudah dipahami oleh mitra tutur dan dilakukan dengan mengandalkan dan mencapai pemahaman bersama atau tujuan komunikasi.

Pengekspresian fungsi direktif, baik dengan strategi langsung, maupun tidak langsung, keduanya tidak semata-mata dilakukan dalam upaya menyampaikan maksud agar efektif dan efisien, tetapi juga dilakukan dalam upaya menjalin hubungan yang harmonis dan akrab dalam pembelajaran di kelas. Hal ini sejalan dengan pandangan Leech (1993:94) yang menyatakan bahwa tujuan yang hendak dicapai dalam sautu peristiwa komunikasi di samping terkait dengan tujuan individu, juga terkait dengan upaya penutur membangun hubungan yang baik dan harmonis dengan membangun kerja sama yang lebih menguntungkan mitra tutur agar interaksi berjalan dengan baik dan lancar.

\section{SIMPULAN}

Berdasarkan temuan penelitian, dikemukakan hasil penelitian sebagai berikut. Pertama, bentuk tindak tutur direktif guru yang direalisasikan dalam wacana interaksi kelas anak tunarungu meliputi tindak tutur direktif modus deklaratif, modus interogatif, dan modus imperatif. Tindak tutur direktif modus deklaratif diwujudkan dalam tuturan direktif bermodus pernyataan keinginan, pernyataan keharusan, pernyataan larangan, pernyataan pengizinan, pernyataan ajakan, pernyataan kritik, dan pernyataan teguran. Tindak tutur direktif modus interogatif diwujudkan dalam tuturan direktif bermodus pertanyaan permintaan klarifikasi, permintaan informasi, permintaan konfirmasi, pertanyaan bermodus alasan, dan pertanyaan permintaan tindakan. Tindak tutur direktif modus imperatif diwujudkan dalam tuturan direktif bermodus imperatif perintah, imperatif suruhan, imperatif permintaan, imperatif larangan, imperatif ajakan, imperatif saran, imperatif harapan, dan imperatif desakan. Dengan kata lain, tindak tutur direktif guru dalam wacana interaksi kelas anak tunarungu diwujudkan secara beragam melalui penggunaan bentuk tuturan dengan varian penanda linguistik tertentu sesuai dengan konteks yang melatari wacana percakapan di kelas dan kebutuhan serta tujuan yang hendak dicapai dalam komunikasi di kelas.

Kedua, fungsi komunikasi yang terkandung melalui tindak tutur direktif guru dalam wacana interaksi kelas anak tunarungu meliputi fungsi direktif memerintah, meminta, melarang, mengizinkan, menyarankan, mengharapkan, mengajak, menegur, dan memancing. Dengan kata lain, bentuk tindak direktif yang diwujudkan guru dalam wacana interaksi kelas anak tunarungu merepresentasikan beragam fungsi direktif sesuai dengan konteks yang melatari wacana percakapan di kelas dan kebutuhan serta tujuan yang hendak dicapai dalam komunikasi di kelas.

Ketiga, strategi perealisasian tindak tutur direktif guru dalam wacana interaksi kelas anak tunarungu meliputi strategi langsung dan strategi tidak langsung. Penggunaan strategi langsung tersebut dilakukan guru untuk memerintah, meminta, melarang, mengizinkan, menyarankan, mengharapkan, dan menegur. Dalam hal lain, strategi tidak langsung juga digunakan untuk menyatakan fungsi direktif 
memerintah, meminta, melarang, menegur, dan memancing. Dengan kata lain, bentuk direktif yang merepresentasikan fungsi direktif tertentu direalisasikan guru secara beragam sesuai dengan konteks yang melatari wacana percakapan di kelas dan kebutuhan serta tujuan yang hendak dicapai dalam komunikasi di kelas.

\section{UCAPAN TERIMA KASIH}

Artikel ini disusun berdasarkan hasil penelitian yang dilaksanakan pada tahun 2011 dengan dukungan anggaran DIPA UM. Ucapan terima kasih disampaikan kepada Lembaga Penelitian UM yang telah memfasilitasi penelitian ini. Ucapan terima kasih disampaikan juga kepada para pengurus yayasan terutama kepala sekolah dan guru SMALB YPTB Malang yang telah memungkinkan penelitian ini terlaksana dengan baik. Kepada para guru yang telah membantu mentranskripsikan percakapan dalam interaksi pembelajaran di kelas terutama berkaitan dengan transkripsi bahasa isyarat ke dalam teks tertulis telah pula turut memberi andil besar terhadap terlaksananya penelitian ini.

\section{DAFTAR PUSTAKA}

Barnes, D. 1976/1992. From Communication to Curriculum. London: Penguin (Second edition, 1992, Portsmouth, NH: Boynton/Cook-Heinemann).

Bellack, A.A., dkk. 1966. The Language of the Classroom. Columbia: Teacher College.

Burton, D. 1981. "Analysis of Spoken Discourse" dalam Malcolm Coulthard dan Martin Montgomery (Ed.). 1981. Studies in Discourse Analysis. London: Routledge and Kegin Paul.

Cazden, C.B. 1972. "Problem for Education: Language as Curriculum Conten and Learning Einviroment" dalam Child Language and Education. New York: Holt, Rinehart, and Winston.
Chaudron, C. 1988. Second Language Classroom - Research on Teaching and Learning. New York: Cambridge University Press.

Cook, V. 2000. Second Language Learning and Language Teaching. Beijing: Foreign Language Teachingand Research Press.

Coulthard, Malcolm. 1978. An Introduction to Discourse Analysis. London: Longman Group Limited.

Direktorat PLB. 2004. PedomanPengembanganKurikulumPendidikanLuarBiasa. Jakarta: Direktorat PLB Depdiknas.

Fairclough, N. 1998. Language and Power. London: Longman

Jumadi. 2005. "Representai Power dalam Wacana Kelas: Kajian Etnografi Komunikasi di SMA Negeri 1 Malang". Disertasi. Tidak Diterbitkan. Malang: Pascasarjana Universitas Negeri Malang.

Kartomihardjo, S. 1993. Analisis Wacana dan Penerapannya pada Beberapa Wacana. Dalam Bambang Kaswanti Purwo (Ed.), PELLBA 6. Yogyakarta: Kanisius.

Karim, A. 2008. "Penggunaan Tindak Imperatif dalam Wacana Kelas (Kajian Etnografi Komunikasi di Madrasah Al-Khairat Palu". Disertasi. Tidak diterbitkan. Malang: Pascasarjana Universitas Negeri Malang.

Leech, G. 1993. Prinsip-Prinsip Pragmatik. Terjemahan M.D.D. Oka tahun 1993. Jakarta: Universitas Indonesia.

Martinich, A.P. 2001. The Philosophy of Language. Fourth Edition. New York: Oxford University Press.

Mey, Y. 1993. Pragmatics: An Introduction. Cambridge, Massachusetts: Blackwell Publishers Ltd.

Miles, M. B. dan Huberman, A M. 1992. Analisis Data Kualitatif. Terjemahan oleh Tjetjep Rohidi. Jakarta. Universitas Indonesia Press. 
Ninio, A. dan Snow, C. E. 1996. Pragmatic Development. Colorado: Westview Press, Inc.

Parrish, B. 2004. Teaching Adult ESL A Practical Introduction. New York, NY: McGraw Hill.

Sinclair, J. Mc. dan Coulthard, R. M. 1975. Towards an Analysis of Discourse. Oxford: Oxford University Press.

Sinclair, J. Mc. dan Brazil, D. 1982. Teacher Talk. Oxford: Oxford University Press.
Sperber, D. dan Willson, D. 2009. Toeri Relevansi Komunikasi dan Kognisi. Terjemahan oleh Abdul Syukur Ibrahim (ed.). Yogyakarta: Pustaka Pelajar.

Stubbs, M. 1983. Discourse Analysis, the Sociolinguistic Analysis of Natural Language. Oxford: Basil Balckwell.

Tannen, D. 194. Gender and Discourse. Oxford: Oxford University Press.

Wijana, I D.P. 1996. Dasar-dasar Pragmatik. Yogyakarta: Penerbit Andi. 